\title{
Association between Adiponectin and Insulin Resistance among Sudanese Males with Type 2 Diabetes Mellitus
}

\section{Eman Ahamed Almakey}

Faculty of Medicine, University of Gezira

Ahmed Mohamed Makeen

Faculty of Medicine, International University of Africa

Osman Khalafalla Saeed

Faculty of Medicine, University of Gezira

Khalid Abdelsamea Mohamedahmed ( $\nabla$ khalid.gu89@gmail.com )

Faculty of Medical Laboratory Science, University of Gezira https://orcid.org/0000-0001-7084-6106

\section{Research Article}

Keywords: Adiponectin, Insulin resistance, Diabetes Mellitus, HOMA-IR, Sudanese males.

Posted Date: June 3rd, 2021

DOI: https://doi.org/10.21203/rs.3.rs-582913/v1

License: (a) (i) This work is licensed under a Creative Commons Attribution 4.0 International License. Read Full License

Version of Record: A version of this preprint was published at Chinese Journal of Medical Research on June 30th, 2021. See the published version at https://doi.org/10.37515/cjmr.091X.4202. 


\section{Abstract \\ Background}

Adiponectin is associated with improved systemic insulin sensitivity and profound positive effects in adipose tissue, such as increasing mitochondrial density in adipocytes, reducing adipocyte size, and effective esterification of free fatty acids on lipid storage The factor performs forward transcriptional regulation. Diabetes and its complications are considered to be one of the main causes of morbidity and mortality worldwide.

\section{Objectives}

The aim of this study was to correlate serum levels of adiponectin with insulin resistance in Sudanese males' type 2 diabetes mellitus.

\section{Methodology:}

A case-control community-based study carried out among 126 patients with T2DM as cases group (mean ages $45.2 \pm 5.4$ years); and 126 normal healthy individuals as controls group (mean ages $44.7 \pm 5.4$ years as) in Aldaraga Diabetic Center, Wad Medani, Gezira State, Sudan. About Five $\mathrm{mL}$ of fasting venous blood was obtained from all participants. $\mathrm{HbA}_{10}, \mathrm{FPG}, \mathrm{FPI}$, serum Adiponectin, and (HOMA)-IR were analyzed. SPSS (v 20.0) was used for data analysis.

\section{Results}

The mean of serum adiponectin in the cases group $(3.03 \pm 0.90 \mu \mathrm{g} / \mathrm{ml})$ was lower than the control group $(6.02 \pm 4.24 \mu \mathrm{g} / \mathrm{ml})$ giving highly significant differences -between them $(P=$ value $\leq 0.000)$. HbA1c and Homeostasis Model Assessment of Insulin Resistance index (HOMA-IR) differed significantly between the two groups (P-value $\leq 0.000$ ). Serum adiponectin concentrations correlated significantly negative with HOMA IR $(r=-0.149$, P-value $=0.002)$.

\section{Conclusion}

We concluded that low plasma adiponectin level was predictive of future development of Insulin resistance in Sudanese males.

\section{Introduction}


Adipose tissue dose not simply store fat, energy storage, and insulation but is also an important endocrine organ that secretes bioactive proteins, into the circulation, such as tumor necrosis factor (TNFa) and adiponectin (1), although it can also be secreted by epicardial fat, hepatocytes and skeletal muscle (2). Adiponectin regulates the metabolism of lipids with anti-atherogenic and insulin-sensitizing activities; studies have shown an inverse relationship between adiponectin and metabolic syndrome (3). Insulin resistance is a major feature in the etiology of obesity and type 2 diabetes (2). Adiponectin is a regulator of glucose and energy homeostasis (4). Homeostasis is the embodiment of integrated metabolic reactions and a large network of signaling pathways designed to stabilize life and function (5). Insulin is an integral part of this regulatory network and affects all of its parts. Insulin resistance it was associated with other risk factors for the development of type 2 diabetes, obesity, dyslipidemia, hypertension, and hypercoagulopathy, grouped under the term hyperinsulinemic/insulin resistance syndrome $(X)$ or currently, the metabolic syndrome (6). Adiponectin has been shown to increase insulin sensitivity and decrease plasma glucose by increasing tissue fat oxidation, adiponectin levels tend to decrease as a person ages and body mass index increase (7). Obesity and hyperinsulinemia are suggested as the potential mechanisms for the suppression of adiponectin levels in the body and ethnicity may play a role in adiponectin regulation among different subjects (8). Diabetes is a chronic disease that requires ongoing medical care and education to prevent acute complications and reduce the risk of long-term complications (9). Patients with hyperglycemia should receive treatment and care by a team of health professionals coordinated by a doctor, including nurses, nutritionists, and social workers (10). Diabetes was previously considered a rare disease in Sudan (9). Diabetes mellitus is a chronic, lifelong disease resulting from a defect in insulin secretion, insulin resistance, or both. Insulin resistance occurs when cells in the body (liver, skeletal muscle, and adipose/fat tissue) become less sensitive and eventually resistant to insulin, Glucose can no longer be absorbed by the cells but remains in the blood, triggering the need for more and more insulin (hyperinsulinemia) to be produced in an attempt to process the glucose (11).

\section{Materials And Methods}

\section{Ethical approval:}

Ethical approval for the study was obtained from the Ethics and Research Committee, Faculty of Medicine, University of Gezira and Ministry of Health, Gezira State. The study objectives and procedure were explained to participants, and verbal consent was obtained from each participant.

\section{Study design and area:}

This study was a case-control community-based study carried out at Aldaraga Center for Diabetes Care at Wad Medani, Gezira State, Central Sudan (located about $186.9 \mathrm{Km}$ Southeast of Khartoum on the west bank of the Blue Nile River, It is the Capital of Gezira State).

\section{Study sample:}


A total of 252 adult male participants (126 patients with T2DM as cases and 126 non-diabetic healthy subjects as control) with age range ( $40-65$ years old). Both the non-diabetic control group and the diabetic group were selected to have matching BMI and a similar distribution of age that live in the same area. Data were collected by using a detailed and structure questionnaire, included close-ended questions. The duration of the study was from September 2019 - April 2020.

\section{Inclusion Criteria:}

All T2DM with oral hypoglycemic agents, non-ketosis, and duration of diabetes $>1$ year, were in good general health and had normal kidney and liver function.

\section{Exclusion Criteria:}

Who disagree to participate, if they had active cardiac, hepatic, or renal disease or if they had long-term complications from diabetes, diabetic subjects treated with insulin were not included in this study.

\section{Sample collection:}

About Five $\mathrm{mL}$ of fasting venous blood was obtained from all participants. $1 \mathrm{ml}$ of blood was put in EDTA container for $\mathrm{HbA}_{1 \mathrm{c}}$ measurement; $1 \mathrm{ml}$ was put in fluoride oxalate container for measurement of plasma glucose, and $3 \mathrm{ml}$ were put in lithium heparin container, then plasma was separated after centrifugation at $3000 \mathrm{~g}$ for 10 minutes and used for biochemical measurements (lipid profiles and adiponectin concentration) using standard laboratory methods. The collected serum for adiponectin analysis was separated within one hr. of collection and was stored at $-80^{\circ} \mathrm{C}$ until the measurement of total adiponectin concentration, which was within a month.

\section{Sample analysis:}

Plasma samples were analyzed for different biochemical parameters, using A15, Biochemistry Calibrator (Bio-Systems code. 18011), and Serum adiponectin concentration was measured by using enzyme-linked immunoassay kits (ELISA Kit).

\section{Software:}

A15 - Y15 service manual English, TESE00005-11-ING. May -2010. Biosystems, S.A. Costa Brava, 30, 08030 Barcelona- Spain http://www.biosystems-sa.com

\section{Statistical analysis:}

The data were statistically analyzed using IBM SPSS, Version 25 statistical program (SPSS Inc, Chicago, IL, USA) was used for descriptive and analytical statistics, Independent Sample T. test, and Pearson correlations to analyzed the associations' differences and correlations between the study groups. The significance was considered when the $P$-value is less than $0.05 \quad(P<0.05)$. 


\section{Results}

Comparison of means of anthropometric measurements and biochemical parameters between the study groups:

Table 1 showed Waist, HbA1c, FBG, fasting plasma insulin, and HOMA-I.R were significantly higher in diabetics compared to non-diabetics $(P$-value $<0.05)$ while serum adiponectin was significantly lower in diabetics compared to non-diabetics $(P$-value $=0.001)$.

Table 1: Comparison of anthropometric measurements and biochemical parameters between the study groups:

\begin{tabular}{|c|c|c|c|}
\hline Anthropometric and Biochemical parameters & $\begin{array}{l}\text { T2DM } \\
(n=126)\end{array}$ & $\begin{array}{l}\text { Control } \\
(n=126)\end{array}$ & $P$ value \\
\hline \multicolumn{4}{|l|}{ Mean \pm SD } \\
\hline Age (years) & $45.2 \pm 5.4$ & $44.7 \pm 5.4$ & 0.070 \\
\hline BMI $\left(\mathrm{kg} / \mathrm{m}^{2}\right)$ & $26.03 \pm 0.98$ & $24.54 \pm 2.55$ & 0.287 \\
\hline Waist (cm) & $104.14 \pm 1.10$ & $82.15 \pm 1.67$ & $0.002^{*}$ \\
\hline Serum Adiponectin $(\mu \mathrm{g} / \mathrm{ml})$ & $3.03 \pm 0.90$ & $6.02 \pm 4.24$ & $0.001 *$ \\
\hline Glycated hemoglobin $\mathrm{HbA}_{1 \mathrm{c}} \%$ & $9.27 \pm 1.51$ & $5.03 \pm 0.90$ & $0.000 *$ \\
\hline Fasting blood glucose ((mmol/l) & $8.26 \pm 1.22$ & $5.62 \pm 0.93$ & $0.001^{*}$ \\
\hline Fasting plasma insulin( $\mu \mathrm{lU} / \mathrm{mL})$ & $9.23 \pm 0.98$ & $6.00 \pm 0.82$ & $0.000 *$ \\
\hline HOMA-I.R & $3.39 \pm 0.64$ & $1.49 \pm 0.29$ & $0.000 *$ \\
\hline
\end{tabular}

Data were presented as means \pm SD and t-test used for comparison. (HOMA-I.R) Homeostasis model assessment of insulin resistance. * $P$ value $\leq 0.05$

Comparison of means of Adiponectin $(\mu \mathrm{g} / \mathrm{ml})$ levels in T2DM patients according to the abdominal obesity prevalence $(n=126)$

The results in table 2 showed that diabetic males with abdominal obesity are $27 \%$ Adiponectin $(3.11 \mu \mathrm{g} / \mathrm{ml})$, whereas $73 \%$ without abdominal obesity, Adiponectin $(1.81 \mu \mathrm{g} / \mathrm{ml})$, this result statistically significant (P-value $\leq 0.05)$.

Table 2: Comparison of means of Adiponectin $(\mu \mathrm{g} / \mathrm{ml})$ levels \pm SD in T2DM patients according to the abdominal obesity prevalence $(n=126)$ 


\begin{tabular}{|llll|}
\hline Variable & $\begin{array}{l}\text { T2DM with } \\
\text { abdominal obesity }\end{array}$ & T2DM without abdominal obesity & a value \\
\hline Number and $(\%)$ & $34(27 \%)$ & $92(73 \%)$ & 0.004* \\
\hline Adiponectin $^{\mathrm{b}}(\mu \mathrm{g} / \mathrm{ml})$ & $3.11 \pm 0.88$ & $1.8 \pm 0.94$ & \\
\hline
\end{tabular}

a Abdominal obesity was defined as $W C \geq 88 \mathrm{~cm}$ in male. ${ }^{b}$ Data were presented as means \pm SD and ttest used for comparison. * $P$ value $\leq 0.05$

\section{Correlation of adiponectin $(\mu \mathrm{g} / \mathrm{ml})$ levels in T2DM patients}

Table 3 illustrates that serum levels of adiponectin correlated negatively with WC, BMI, HOMA-IR and LDL ( $P$-value $<0.05)$, and Pearson correlation ( $r$ values) were weak and positively correlated with HDL $(r=$ 0.59$, P-value $=0.001)$.

Table 3: Correlation of adiponectin $(\mu \mathrm{g} / \mathrm{ml})$ levels in T2DM patients $(n=126)$

\begin{tabular}{|lll|}
\hline Risk factors & r. value* & $P$ value \\
\hline WC $(\mathrm{cm})$ & -0.191 & $\mathbf{0 . 0 0 1}$ \\
\hline BMI $\left(\mathrm{Kg} / \mathrm{m}^{2}\right)$ & -0.001 & $\mathbf{0 . 0 3 7}$ \\
\hline Insulin Resistance index (HOMA-I.R) & -0.015 & $\mathbf{0 . 0 0 2}$ \\
\hline High density lipoprotein & 0.59 & $\mathbf{0 . 0 0 1}$ \\
\hline Low density lipoprotein & -0.101 & $\mathbf{0 . 0 0 1}$ \\
\hline
\end{tabular}

*Pearson coefficient used for correlation. ${ }^{*} \mathrm{P}$ value $\leq 0.05$

\section{Discussion}

In the current study, we analyzed data to find the associations between different parameters in T2DM cases and control groups, after adjusting for age, gender and BMI. There were highly significant differences $(P$-value $=0.001)$ in comparison of means serum adiponectin among diabetics $(3.03 \pm 0.90$ $\mu \mathrm{g} / \mathrm{ml})$ and non-diabetics $(6.02 \pm 4.24 \mu \mathrm{g} / \mathrm{ml})$, but the difference no significant difference in the BMI distribution between the two study groups (P-value $=0.287$ ). In T2DM there was a significant increase in WC mean and marginally decreased in control subjects $(P$-value $=0.002)$. This finding is in agreement with that of Bogan and Lodish's study, (12). There were significant differences in $\mathrm{HbA}_{1 \mathrm{c}}$ differed significantly between the T2DM and control groups (P-value $=0.000)$, the T2DM group had a higher mean of (9.27 $\pm 1.51 \%)$. Similar reports have been published by Cnop et al. (13) and Valsamakis et al. (14) in 2003. Fasting plasma insulin and FPG differed significantly between the T2DM and control groups (Pvalue $=0.000$ and 0.000 respectively). Homeostasis Model Assessment of Insulin Resistance index 
(HOMA-IR) was calculated by applying the following formula: (fasting serum insulin $(\mu \mathrm{U} / \mathrm{ml}) \times$ fasting plasma glucose (mmol/L)/22.5); the diabetic group had a higher mean of HOMA-IR (3.39 $\pm 0.64 \%)$, whereas the control group had a mean level of $(1.49 \pm 0.29 \%)$ giving the highly significant difference between the two groups ( $P$-value $=0.000)$. Adiponectin concentrations significantly negative correlated with HOMA IR $(r=-0.149$, P-value $=0.002)$. This finding consistent with the study done by Yadavet al. (15). Adiponectin levels are decreased in patients with T2DM, in the same way, high levels are predicted to reduce the risk for T2DM (16). The effect of reduced plasma concentration of Adiponectin predisposes healthy individuals to the later development of insulin resistance (17).

Diabetic males with abdominal obesity are $27 \%$ (Adiponectin $=3.11 \mu \mathrm{g} / \mathrm{ml}$ ), whereas $73 \%$ without abdominal obesity (Adiponectin $=1.81 \mu \mathrm{g} / \mathrm{ml}$ ). This result statistically significant $(P$-value $\leq 0.05)$. Low levels of adiponectin are closely related to the development of insulin resistance. A negative correlation was also reported between adiponectin levels and WC and fasting serum insulin. Similar results were found in Hypoadiponectinemia in obesity and type 2 diabetes studies by Yamauchi et al. (7).

The serum levels of adiponectin correlated weakly negative with WC, BMI, HOMA-IR- and LDL (P value $\leq$ $0.05)$, and positively with HDL $(r=0.59$, P-value $<0.001)$. Adiponectin concentration is negatively correlated with HOMA-IR, positively correlated with HDL cholesterol, and has nothing to do with age and BMI. Daimon also found a negative correlation between HOMA-IR (independent of BMI) and adiponectin (Daimon, 2003). These results indicated hyperglycemia in T2DM and decrease of FPG and HOMA-IR in control group, these result agree by Carling (18).

\section{Conclusion}

In conclusion, the modern lifestyle, high-fat, diet and lack of exercise have been shown to trigger the development of central obesity with hypoadiponectinemia, hyperlipidemia, insulin resistance, and type 2 diabetes. Now lifestyle changes, including weight loss and exercise, maybe a more effective strategy to improve health and limit insulin resistance.

\section{Declarations}

\section{Acknowledgements:}

I am deeply grateful to my supervisor Prof. Ahmed Mohamed Makeen and co-supervisors Prof. Osman Khalafalla Saeed, whose gave me the golden opportunity to do this wonderful work, this work could have never been possible without his wise guidance and supervision. I would like to say a heartfelt thank to Dr. Mohamed Abdrhman Adrise for his constant guidance, help and support.

Competing interests: The authors declare the following competing interests.

\section{References}


1. Steppan CM, Bailey ST, Bhat S, Brown EJ, Banerjee RR, Wright CM, Patel HR, Ahima RS, Lazar MA. The hormone resistin links obesity to diabetes. Nature. 2001; 409(6818): 307-312. PMID: 11201732. DOI: $1038 / 35053000$.

2. Henry RR. Thiazolidinediones. Endocrinol Metab Clin North Am. 1997; 26(3): 553- 573. PMID: 9314015. DOI: 1016/s0889-8529(05)70267-x.

3. Hung PJ. Control of energy homeostasis and insulin action by adipocyte hormones: leptin, acylation stimulating protein, and adiponectin. Curr Opin Lipidol. 2002; 13(1): 51-59. PMID: 11790963. DOI: 1097/00041433-200202000-00008.

4. Chandram M, Philips SA, Ciaraldi T, Henry RR. Adiponectin: more than just another fat cell hormone?. Diabetes Care. 2003; 26(8): 2442-2450.

5. Saad A, Dalla MC, Nandy DK, Levine JA, Bharucha AE, Rizza RA, Basu R, Carter RE, Cobelli C, Kudva YC, Basu A. Diurnal pattern to insulin secretion and insulin action in healthy individuals. Diabetes. 2012; 61(11): 2691-2700. PMID: 22751690. DOI: 2337/db11-1478.

6. DeFronzo RA, Ferrannini E. Insulin resistance. A multifaceted syndrome responsible for NIDDM, obesity, hypertension, dyslipidemia, and atherosclerotic cardiovascular disease. Diabetes Care. 1991; 14(3): 173-194. PMID: 2044434. DOI: 2337/diacare.14.3.173.

7. Yamauchi T, Kamon J, Waki H, Imai Y, Shimozawa N, Hioki K, Uchida S, Ito Y, Takakuwa K, Matsui J, Takata M, Eto K, Terauchi Y, Komeda K, Tsunoda M, Murakami K, Ohnishi Y, Naitoh T, Yamamura K, Ueyama Y, Froguel P, Kimura S, Nagai R, Kadowaki T. Globular adiponectin protected ob/ob mice from diabetes and ApoE-deficient mice from atherosclerosis. J Biol Chem. 2003; 278(4): 2461-2468. PMID: 12431986. DOI: 1074/jbc.M209033200.

8. Weyer C, Funahashi T, Tanaka S, Hotta K, Matsuzawa Y, Pratley RE, Tataranni PA. Hypoadiponectinemia in obesity and type 2 diabetes: close association with insulin resistance and hyperinsulinemia. J Clin Endocrinol Metab. 2001; 86(5): 1930-1935. PMID: 11344187. DOI: 1210/jcem.86.5.7463.

9. Abdelgadir M; Elbagir M; Eltom M; Berne C; Ahren B. Reduced leptin concentrations in subjects with type 2 diabetes mellitus in Sudan. 2002; 51(3): 304-306. PMID: 11887164. DOI: 10.1053/meta.2002.30504.

10. Evans JM, Newton RW, Ruta DA, Mac Donald TM, Morris AD. Socio-economic status, obesity and prevalence of type 1 and type 2 diabetes mellitus. Diabet Med. 2000; 17(6): 478-480. PMID: 10975218.

11. Hayden MR and Tyagi SC. Intimal redox stress: Accelerated atherosclerosis in metabolic syndrome and type 2 diabetes mellitus. Atheroscleropathy. Cardiovasc Diabetol. 2002; 1:3. PMID: 12392600. DOI: 10.1186/1475-2840-1-3.

12. Bogan JS, Lodish HF. Two compartments for insulin-stimulated exocytosis in 3T3-L1 adipocytes defined by endogenous Acrp30 and Glut4. J Cell Biol. 1999; 146(3): 609-620. DOI: 1083/jcb.146.3.609. 
13. Cnop M, Havel PJ, Utzschneider KM, Carr DB, Sinha MK, Boyko EJ, Retzlaff BM, Knopp RH, Brunzell JD, Kahn SE. Relationship of adiponectin to body fat distribution insulin sensitivity and plasma lipoproteins: evidence for independent roles of age and sex. Diabetologia. 2003; 46(4): 459-469. PMID: 12687327. DOI: 1007/s00125-003-1074-z.

14. Valsamakis G, Chetty R, McTernan PG, Al-Daghri NM, Barnett AH, Kumar S. Fasting serum adiponectin concentration is reduced in Indo-Asian subjects and is related to HDL cholesterol. Diabetes Obes Metab. 2003; 5(2): 131-135. PMID: 12630939. DOI: 1046/j.1463-1326.2003.00254.x.

15. Yadav A, Jyoti P, Jain SK, Bhattacharjee Correlation of Adiponectin and Leptin with Insulin Resistance: A Pilot Study in Healthy North Indian Population. Indian J Clin Biochem. 2011; 26(2): 193-196. DOI: 10.1007/s12291-011-0119-1.

16. Ouchi $\mathrm{N}$ and Walsh Adiponectin as an anti-inflammatory factor. Clin Chim Acta. 2007; 380(1-2): 2430. DOI: 10.1016/j.cca.2007.01.026.

17. Dalamaga M, Diakopoulos KN, Mantzoros The Role of Adiponectin in Cancer: A Review of Current Evidence. Endocr Rev. 2012; 33(4): 547-594. DOI: 10.1210/er.2011-1015

18. Carling D. The AMP-activated protein kinase cascade-a unifying system for energy control. Trends Biochem Sci. 2004; 29(1): 18-24. PMID: 14729328. DOI: 1016/j.tibs.2003.11.005. 